\title{
On dative causers in Hungarian
}

\author{
György Rákosi \\ Department of English Linguistics, University of \\ Debrecen \& MTA-DE Research Group for \\ Theoretical Linguistics, Debrecen \\ rakosi.gyorgy@arts.unideb.hu
}

\begin{abstract}
This paper aims at investigating a special, causative use of dative case in Hungarian that has not received much attention in the literature so far. I show that Hungarian dative causers differ from dative causers in the languages of the Balkan Sprachbund, German, or Spanish in important ways. What makes Hungarian dative causers different is that they are not licensed and interpreted via syntactic structure but are lexically determined to be causative given that dative case has a special, causative lexical entry in Hungarian.
\end{abstract}

Keywords: dative causer; oblique causer, unintended causation construction, dative case; Hungarian

\section{Introduction}

This paper aims to investigate whether Hungarian has the kind of unintended causation construction that has been reported to exist in the languages of the Balkan Sprachbund, Spanish, Italian, German, Polish, or in the East Caucasian languages (see, among others, Cuervo 2003; Ganenkov et al. 2008; Kallulli 2006; 2007; Rivero 2004; Schäfer 2008; 2009; 2012). The following German example from Schäfer $(2008,42)$ illustrates this construction:

(1) Dem Hans zerbrach versehentlich die Vase. the.DAT Hans broke unintentionally the.NOM vase 'Hans unintentionally caused the vase to break.'

The oblique causer is often marked with dative in European languages, as is the case in German. ${ }^{1}$ This DP refers to a participant who only accidentally

${ }^{1}$ Dative marking of oblique causers is frequent in European languages, but dative is not the sole option universally. Greek oblique causers are marked with genitive case, and the East Caucasian language Agul uses ad-elative case for the same purpose (Ganenkov et al. 2008). The term oblique causer I adopt from Schäfer (2008; 2009; 2012) as a general term that covers the different morphological instantiations of causers in unintended causation constructions.

1216-8076/\$20.00 C 2014 Akadémiai Kiadó, Budapest 
brings about the change of state denoted by the inchoative verb stem, and who does not necessarily intend this result to happen.

Dative case is used extensively in Hungarian. It marks extracted possessors (see, a.o., Szabolcsi 1983; den Dikken 1999; É. Kiss 2000), infinitival subjects by certain matrix predicates (Tóth 2000; Rákosi 2006), certain types of secondary predicates (Matushansky 2012), as well as adjecti$\mathrm{val} /$ nominal fronted predicates (Ürögdi 2006). It is also a marker of a wide variety of goals, recipients, affected participants and experiencers (Rákosi 2006) as well as ethical datives (Rákosi 2008). Given this functional richness, one may well expect dative case to license unintended oblique causers, too. Indeed, (1) can be rendered in Hungarian more or less literally: ${ }^{2}$

(2) János-nak véletlenül el-tört a váza.

John-DAT accidentally PRT-broke the vase.NOM

'John accidentally broke the vase.'

Nevertheless, many Hungarian speakers find sentences like (2) somewhat marked or even odd, unless a special supportive context is created. And, as we will see, many examples cited in the literature on oblique causers simply do not seem to work in Hungarian, or they at least have a marked character. It is probably no accident that dative causers, to my best knowledge, have not been discussed in the literature on Hungarian.

In this paper, I want to argue that the Hungarian dative causer construction does exist, but it is not grammatically equivalent to the kind of unintended causation construction that one finds in many other languages, including German. In certain ways, it is more akin to the use of the English prepositions to/for when they have causative overtones (as in the sentence To me, the kids will never do anything in the house). The paper proceeds along this argumentation as follows. In section 2, I show that Hungarian dative causers can be three-way ambiguous in exactly the same way as has been reported by Schäfer $(2008,2012)$ and Ganenkov et al. (2008) for the languages mentioned above. However, what is felt to be the most marked reading in other languages, often turns out to be the most easily accessible reading in Hungarian. In section 3, I dive deeper into the grammar of Hungarian dative causers to reveal more about their distinctive character. In section 4, I provide arguments that the causer reading is a genuinely distinct use of these datives, and cannot be treated as a simple inferen-

${ }^{2}$ Unfortunately, the English adverb unintentionally does not have a closely matching translational equivalent in Hungarian, that is why I use the adverb véletlenül 'accidentally' to facilitate the unintended causation reading in (2). 
tial option on an assumed underlying affected semantics. In section 5, I suggest that Hungarian dative causers are best treated as being lexically specified for causation, rather than feeding on a causatively interpreted syntactic layer of decomposition (as is argued in Cuervo (2003); Kallulli (2006; 2007), and Schäfer 2008; 2009; 2012, among others.). Finally, section 6 concludes this paper.

\section{Three interpretative options of oblique causers and the Hungarian scene}

\subsection{Three readings for oblique causers}

Ganenkov et al. $(2008,177)$ argue that what they call the involuntary agent construction in Agul (i.e., the oblique causer construction) has three different interpretations, which they describe as follows:

(i) The participant affects the Patient accidentally, without noticing what $\mathrm{s} / \mathrm{he}$ is doing.

(ii) The participant involuntarily lets something happen by overlooking and not making enough efforts to prevent the situation.

(iii) The participant finally (as a result of efforts) succeeds in doing something, although it is not quite expected.

The previous literature has mostly focused on reading (i), but Ganenkov et al. (2008) point out in reference to Kittilä (2005) that besides many East Caucasian languages, the same ambiguity is found in Bagwalal, Finnish and Thomson River Salish in oblique causer constructions.

Schäfer (2008, 107-108) shows that the German, Italian and Greek oblique causer constructions allow for exactly the same three readings. I quote his German example to illustrate:

(3) als dem Mädchen die Tür (dann doch noch) aufging

when the.DAT girl the.NOM door then after all open.went

Reading A: 'The girl accidentally opened the door (because she pushed it with her elbow while playing with the toys on the floor).'

Reading B: (Father told the girl to hold the door so that the wind could not open it, but her efforts were not enough.) 'The girl accidentally opened the door/let the door open.'

Reading C: (All the children tried but no one could open the tightly closed door, however it so happened that) 'The girl managed to open the door.'

Acta Linguistica Hungarica 61, 2014 
Both Ganenkov et al. (2008) and Schäfer (2008) treat this variation as an instance of polysemy. What is common in these three readings is that the oblique causer participant has little control over the whole of the event - unlike in the agentive reading of the corresponding transitive construction (The girl opened the door).

Both note nevertheless that the third reading seems to be qualitatively different from the first two. In this reading, the referent of the oblique marked participant intentionally aims at performing the event denoted by the verb, but (s)he only accidentally manages, as it were, to do so. This is the reason why reading $\mathrm{C}$ is blocked in the presence of a modifier spelling out unintentionality. Interestingly, this reading is also blocked by intentionality adverbs, as noted by Schäfer $(2008,108):^{3}$

(3) als dem Mädchen die Tür*absichtlich/versehentlich aufging when the.DAT girl the.NOM door on.purpose/unintentionally open.went

Reading A \& B: grammatical with versehentlich 'unintentionally'; ungrammatical with absichtlich 'on purpose'

Reading C: ungrammatical with both adverbs

Thus while the C-type dative causer participant intentionally performs an activity aimed at a specific result state, the construction still describes the coming about of this result state as somewhat accidental and outside of the intentional control of this participant.

Schäfer $(2008,107)$ explicitly notes that in German reading $\mathrm{A}$ is the most prominent and the most easily accessible one by default. The other two readings strongly require specific accommodating contexts or facilitating modification in the clause. Thus readings $\mathrm{B}$ and $\mathrm{C}$ have a somewhat marked character, which is a trait that Schäfer captures by proposing a syntactic analysis that renders the semantic relation between the oblique causer and the event denoted by the extended verbal layer of the clause rather vague and unspecified. ${ }^{4}$ It is expected under such an analysis that the semantically weakest reading (reading A) is the most accessible one, and the other two (readings B \& C) require more specific triggers.

Interestingly, Hungarian appears to display the inverse pattern of markedness, as I discuss immediately below in the next subsection. I focus on reading A (the 'true unintended causation' reading) and reading $\mathrm{C}$

${ }^{3}$ As a shorthand, I adopt Schäfer's (2008) notation reading A/B/C to be able to refer to these readings.

${ }^{4}$ This analysis is briefly discussed in 5.2 below. 
(the 'accidentally manages to' reading) in the rest of the paper for ease of exposition, as these two readings provide a clear contrast.

\subsection{The Hungarian scene}

I claimed in the introduction that in Hungarian, unlike in other languages discussed in the literature, native speakers seem to have less favourable judgements of the dative causer construction, and intuitions about the availability of this dative reading seem to vary across specific inchoative examples. Outside of an accommodating context, many of the purported examples sound awkward.

To get a better grip on this intuition, consider the following Spanish sentence pair (Cuervo 2003, 189) in contrast to the corresponding Hungarian examples in (5):

(4) a. A quién se le rompió el florero?

who.DAT se cl.DAT broke the vase

'Who broke the vase accidentally?'

b. Quién rompió el florero?

who.NOM broke the vase

'Who broke the vase?'

(5) a. Ki-nek tört el a váza?

who-DAT broke PRT the vase.NOM

b. Ki törte el a váz-át?

who.NOM broke PRT the vase-ACC

'Who broke the vase?'

Cuervo claims that in the context when a parent comes home and finds a vase broken, (4a) is "more natural (and more polite)" than the transitive (4b).

In the selfsame context, $(5 \mathrm{~b})$ is the question that a parent would ask in Hungarian. The transitive break can be interpreted either as having an agent subject, or a non-agentive cause. This latter construal denotes essentially the same accidental/unintentional causation event as a corresponding dative causer construction would on reading A in German or in Spanish. The question in (5a) is barely acceptable even in the above described context, where strong contextual clues are given. Nevertheless, speakers who totally reject the unintended causation reading of (5a) even when a facilitating context is presented, can accept this sentence as an 
expression of reading $\mathrm{C}$. This reading requires a context in which each of the children tries to break the vase-because, for example, all the family hate it - and the parent makes an inquiry about who has managed to achieve this. ${ }^{5}$

The true unintended causation reading is available though with inchoatives if they occur in declarative sentences. There seem to be two factors that induce more positive judgements. First, if the accidentally caused result state is more naturally construed as a side effect of the activity that the referent of the dative causer is carrying out, then the construction is judged more acceptable.

(6) a. Kati-nak megint össze-tört egy pohár (takarítás közben). Kate-DAT again PRT-broke a glass.NOM cleaning during 'Kate unintentionally broke a glass yet again during the cleaning.'

b. János-nak megint össze-tört egy fényképezőgép (az esküvőn). John-DAT again PRT-broke a camera.NOM the wedding.on 'John unintentionally broke a camera yet again during the wedding.'

It is easier to find a causal link between the breaking of the glass and the activity of cleaning than between the breaking of a camera (whether

${ }^{5}$ If the dative causer is focussed, judgements concerning reading A gets worse even in declarative sentences (Péter Pelyvás, p.c.). The focussed constituent occupies an immediately preverbal position in Hungarian, separating the particle from the verb. Compare (i) and (ii) below. The two sentences minimally differ in that the dative causer is focussed in (ii).

(i) János-nak el-tört a váza.

John-DAT PRT-broke the vase.NOM

'John accidentally broke the vase."

(ii) János-nak tört el a váza.

John-DAT broke PRT the vase.NOM

'It was John who broke the vase.'

$W h$-words also occupy the preverbal focus position, see the examples in (5).

The marked nature of the focused dative causer construction as an expression of reading $\mathrm{A}$ is probably due to the same reason in the case of (5a) above and (ii). It is part of the background information that somebody broke the vase in both cases, and this context biases the use of the transitive construction, which is canonically used to express causative events. Note nevertheless that reading $\mathrm{C}$ is available both in (5a), (i) and (ii). The availability of this interpretation, being semantically the strongest out of the three readings discussed above $(\mathrm{A} / \mathrm{B} / \mathrm{C})$, seems to be a sufficient trigger for the licensing of the dative causer in an otherwise non-causal intransitive construction (on the absence of causality in anticausative constructions in Hungarian, see Rákosi 2012). 
it is John's or somebody else's) and the activity of attending a wedding. Therefore (6b) sounds somewhat more marked than (6a), or it does so at least in the absence of a supportive context.

Second, the unintended causation reading is generally felt to be better if the predicate describes an event that can be naturally conceptualised as happening by itself, in the absence of a prominent outside cause. Compare (7a) and (7b) in this respect:

(7) a. Kati-nak fel-robbant egy kémcső.

Kate-DAT PRT-exploded a test.tube.NOM

'Kate accidentally exploded a test-tube.'

b. Kati-nak be-tört egy ablak.

Kate-DAT PRT-broke a window.NOM

'Kate accidentally broke the window.'

Windows do not normally break by themselves, whereas the chemical substance in a test-tube can explode without the intervention of an outside force (or at least so can laymen conceptualise the situation). (7a) is therefore felt to be more natural (or, more acceptable) than (7b) because the former event can be seen as a true accident unlike the breaking of a window which too can, but is less likely to happen accidentally.

Note that each sentence in (6) and (7) can perfectly well be construed under reading $\mathrm{C}$, too. Then $(7 \mathrm{~b})$, for example, requires a context in which Kate is trying to break windows and eventually she succeeds. Reading $\mathrm{C}$ is perhaps less natural with these particular examples that have been picked to illustrate the unintended causation reading, but it still is the reading that every native speaker accepts for each of these inchoative structures even if they are not willing to accept reading A. Certain triggers make reading $\mathrm{C}$ very prominent, and no native speaker finds such sentences marked or degraded in any way. Manner modification is one such trigger, consider (8):

(8) Kati-nak könnyen ki-nyílt az ajtó.

Kate-DAT easily PRT-opened the door.NOM

'Kate managed to open the door easily?'

Reading $\mathrm{C}$ is fully acceptable for everyone with the manner adverb, because the modifier can imply the presence of a certain degree of intentionality that this reading can feed on.

Before proceeding to a discussion of further properties of Hungarian dative causers, I intend to stress once again the fact that reading $\mathrm{C}$ seems 
to be the least marked option in Hungarian in the sense that it is easily available in every facilitating context. Reading A, on the other hand, is not always felt to be as natural by native speakers even if a facilitating context is present. Thus Hungarian contrasts with the languages known in the literature to have the oblique causer construction, inasmuch as the most prominent reading in those languages is the unintended causation reading, or reading $\mathrm{A}$.

\section{Digging further into the grammar of Hungarian dative causers}

Oblique causers are licensed cross-linguistically by intransitive alternates of the externally caused change of state verbs of Levin \& Rappaport Hovav (1995). ${ }^{6}$ They are not licensed in transitive structures. I quote the following Agul examples from Ganenkov et al. (2008, 179), but much the same holds for the rest of the languages mentioned in the introduction: ${ }^{7}$

(9) a. ruš.a k'ež lik'i-ne

girl.ERG letter.ABS write-PAST

'The girl wrote a letter.'

b. *ruš.a-f-as k'ež lik'i-ne

girl-AD-ELAT letter.ABS write-PAST

'The girl accidentally wrote a letter.'

c. *za-f-as ruš.a k'ež lik'i-ne

I-AD-ELAT girl.ERG letter.ABS write-PAST

'I accidentally made the girl write a letter.'

That (9b) is ungrammatical as an alternative to (9a) is non-surprising: write requires an agentive subject, but the ad-elative case-marked oblique can only refer to non-agentive causers. (9c) is also ungrammatical as a causative construction. Note that the periphrastic causative in the English rendering of the intended meaning of the Agul sentence is perfectly

${ }^{6}$ This is the class of what Reinhart $(1996 ; 2002)$ refers to as decausativized verbs, i.e., intransitives that have a transitive alternate whose subject can be interpreted either as an agent or as a non-agentive cause (e.g.: break, explode, open, etc.). Those intransitives that Levin and Rappaport-Hovav (1995) classify as internally caused (e.g.: blossom, bloom, etc.) are much less likely to license oblique causers cross-linguistically, or at least there is variation across languages and examples.

${ }^{7}$ Oblique causers are marked by ad-elative case in Agul. Ad-elative is a locative case meaning 'motion from location near a landmark'. 
well-formed both syntactically and semantically. Nevertheless, it still holds cross-linguistically that transitives do not allow for oblique causers, dative causers included. ${ }^{8}$

But Ganenkov et al. $(2008,180)$ also mention an interesting apparent Agul counterexample to this generalisation:

(10) za-f-as ruš.a guni çut'u-ne

I-AD-ELAT girl.ERG bread.ABS eat-PAST

'I managed to feed the girl with bread.'

They comment on this sentence as follows: "One can suppose that the acceptability of $[(10) \ldots]$ is due to the factor that the Involuntary Agent with the verb çut'as 'eat' is not just an instigator of the event, but is involved in the caused event as well." This description suggests that (10) may illustrate an interesting lexical arity-increasing operation, one that also changes the semantics of the verb (note that they translate the Agul verb meaning 'eat' as 'feed').

If we try to translate (9c) and (10) into Hungarian using dative causers, the result is perfectly grammatical: ${ }^{9}$

(11) a. Nek-em meg-írta a lány a level-et.

DAT-1SG PRT-wrote the girl.NOM the letter-ACC

'I made the girl write the letter/I managed to get the girl to write the letter.'

b. Nek-em meg-ette a lány a kenyer-et.

DAT-1SG PRT-ate the girl.NOM the letter-ACC

'I made the girl eat the bread/I managed to get the girl to eat the bread.'

Starting with (11b), notice that there is no shift in the meaning of the verb, eszik 'eat' has exactly the same meaning with or without the dative causer. Nor does (11b) require the dative participant to be involved directly in the caused event. (11b) can be true if the speaker is not physically present in the scene, but only makes a request through the phone. The same considerations apply to (11a).

If we revisit the inchoative constructions discussed in section 2.2., it turns out that they are well-formed under a relatively loose causation reading in which no strict contingency is required between the causer and the result state. Compare (12a) and (12b) in this respect:

${ }^{8}$ See Fauconnier 2011 for a thorough typological survey.

9 The dative in these sentences can also be construed as an affected (beneficiary) dative or as a recipient in (11a). These readings are irrelevant for this discussion, but I return to them in section 4 . 
(12) a. János-nak megint fel-robbant egy kémcső.

John-DAT again PRT-exploded a test.tube.NOM

'John accidentally exploded a test-tube yet again.'

b. János-nak megint fel-robbant egy erőmü.

John-DAT again PRT-exploded a power.plant.NOM

'John accidentally exploded a power plant yet again.'

(12b) can describe a situation in which John is an operator in a national power plant management center, and he does not recognise a warning sign coming from one of the plants that he supervises. Such readings do not seem to be supported by dative causers in other languages. Kallulli (2006, fn. 20) argues in a footnote that the unintended causation reading in Albanian probably requires a spatial contiguity between the dative and the nominative participants. The contiguity is often present in Hungarian, too, but as (12b) testifies, it does not necessarily have to hold.

What the data in (11) and (12) suggest is that Hungarian dative causers might be able to combine with any predicate type. This indeed is the case:

(13) a. János-nak jobban dolgoznak a munkások.

John-DAT better work the workers.NOM

'John gets the workers working better.'

b. János-nak szépen gurul a labda.

John-DAT nicely rolls the ball.NOM

'John gets the ball rolling nicely.'

c. János-nak csendesek a gyerekek.

John-DAT quiet the kids.NOM

'John can keep the kids quiet/calm.'

(13a) contains an unergative verb, (13b) includes an intransitive motion verb, and we have a stative predicate in (13c) (with the zero form of the copula).

One may object to collapsing these datives with the dative causers that appear by intransitive change of state verbs. But notice that the datives in (13) may allow the same semantic variation as the one we have seen attested in the case of inchoatives. The most natural interpretation in each case is reading C. In (13a), John carries out an activity with the purpose of getting the workers to work better, and he manages to achieve this result. But he does not have to be physically present on the scene, nor does he need to issue any direct command. In fact, (13a) is also true if John does not intend to achieve this result at all. It is enough if he walks

Acta Linguistica Hungarica 61, 2014 
by the construction site without even knowing about the workers - who, however, recognize his presence, and knowing the sort of person that John is, they start working better. This reading is essentially the unintended causation reading, or reading A.

The same can be said of (13b) and (13c) as well. I conclude therefore that (11) and (13) illustrate essentially the same dative causer construction in Hungarian as what we can find in the inchoative examples discussed in section 2.2 .

\section{Dative causers and affected datives}

Dative expressions have a variety of uses in Hungarian, too, as I noted in the introduction to this paper. Consequently, many of the dative causer constructions that we have discussed can in particular be ambiguous between the causation reading and what is known in the literature as the affectedness reading (beneficiary/maleficiary datives). Kallulli (2006) and Schäfer (2012) raise the question whether this semantic variation is the result of true ambiguity or vagueness, and they both conclude that the two uses are grammatically distinct. Hence the dative causer - affected dative ambiguity is a real ambiguity, and the dative causer construction is indeed a distinct construction on its own right.

The intuition behind the postulation of a vagueness-based analysis is that by causing some eventuality, the dative causer participant is also affected somehow by the results. But in the case of reading A, the unintended causation reading, the dative participant does not even have to be aware of what he causes, as we have seen. It is also not necessary that what he causes will have any effect on him. This already raises some conceptual concerns against the vagueness-based analysis. I present here three further arguments that each favour the ambiguity analysis. Each builds on the logic that Kallulli (2006) and Schäfer (2012) follow, namely that one or the other reading may be ruled out in specific constructions. This fact is easy to accommodate within the ambiguity view.

First, it is a cross-linguistic referential constraint on oblique causers that they have to denote animate referents. ${ }^{10}$ Hungarian dative causers can also only be + ANIMATE:

10 Since judgements concerning non-human animate oblique causers are less solid cross-linguistically, I focus on +HUMAN examples in this paper.

Acta Linguistica Hungarica 61, 2014 
(14) a. Kati-nak össze-tört egy pohár.

Kate-DAT PRT-broke a glass.NOM

'Kate unintentionally broke a glass.'

b. *A mosogatógép-nek össze-tört egy pohár.

the dishwasher-DAT PRT-broke a glass.NOM

'The dishwasher unintentionally broke a glass.'

Dative case is otherwise compatible with affected participants in Hungarian, irrespective of whether they have a +ANIMATE denotation or not (see Rákosi 2006, 132-133).

(15) János-nak/ A mosogatógép-nek nem árt a hideg víz.

John-DAT the dishwasher-DAT not harms the cold water.NOM

'Cold water causes no harm for John/the dishwasher.'

Therefore the reason why (14b) is ungrammatical must be something specific to the dative causer construction as a distinct construction type. Note furthermore that (15) only has the affected dative reading, since neither John, nor the dishwasher is interpreted as a cause in this sentence. In (14b), the affectedness reading is unavailable for pragmatic reasons mostly (breaking a glass during the washing-up does not affect the machine), and the causer reading is out for constructional reasons.

Second, the unintended causation reading is facilitated by adverbial expressions that remove the burden of direct (intended) responsibility from the causer. The affected reading is either not available or it is less prominent in these constructions.

(16) Kati-nak megint össze-tört egy pohár a szokásos hanyagsága miatt.

Kate-DAT again PRT-broke a glass.NOM the usual negligence because.of

'Kate unintentionally broke a glass again because of her usual negligence.'

Adverbials expressing lack of intentionality or responsibility therefore create a disambiguating context.

Third, dative causers and affected datives can in fact co-occur in Hungarian, as in the following example:

(17) Nek-em sem nyitották ki a fiúk az ajtó-t Kati-nak.

DAT-1SG neither opened out the boys.NOM the door-ACC Kate-DAT

'Even I didn't manage to get the boys to open the door for Kate.' 
(17) is a transitive structure because it is somewhat difficult to construe similar inchoative examples that sound natural. ${ }^{11}$ Since I have argued that the dative causer in (17) instantiates the same phenomenon that dative causers instantiate in inchoatives, (17) provides strong support for the claim that the causation reading and the affectedness reading of datives in Hungarian are grammatically distinct. As such, they are mutually compatible with each other. Therefore the observed variation in meaning is an instance of true ambiguity, and not vagueness.

\section{The Hungarian dative causer as a lexical phenomenon}

\subsection{A lexicalist analysis}

In the previous sections, we have established three important facts about Hungarian dative causers. First, they are ambiguous between 3 different readings that have been reported for other languages in the literature. But the reading that is evidently the default in other languages - the true unintended causation reading - appears to be marked in Hungarian, and many contexts favour the semantically stronger 'accidentally manages to' reading. Second, Hungarian dative causers are not restricted to occur in inchoative contexts, but are free to be inserted in any sentence if the required pragmatic conditions are satisfied. I have tried to argue in section 3 that each of these occurrences is an instance of the same phenomenon. Third, dative causers cannot be reduced to affected datives, as the two are grammatically distinct dative types.

This behaviour is best accounted for if we assume that Hungarian dative causers genuinely introduce causation into the structure where they are inserted, rather than feed on this structure for the causer interpretation to be derived on the fly. To shed some light on how they are capable of doing this, it is illustrative to consider the analogy between dative causers and the verb sikerül 'manages to, succeeds':

(18) János-nak (véletlenül) sikerült a fogyás.

John-DAT accidentally succeeded the losing.weight.NOM

'John (accidentally) managed to lose weight.'

11 The beneficiary reading, which is more easily available in Hungarian than the maleficiary reading, implies the presence of an implicit causer acting teleologically in inchoatives. It is difficult to embed an unintentional causer against the background of this implicature.

Acta Linguistica Hungarica 61, 2014 
(19) János-nak/*A mosógép-nek jól sikerült a teszt. John-DAT the dishwasher-DAT well succeeded the test.NOM 'John/*The dishwasher succeeded with the test well.'

The verb sikerül can take two DP arguments, one of which is a dativemarked causer of a sort. Sikerül, just like its English counterpart manage, often implies a try, but this implication can be cancelled (see Baglini \& Francez 2013 for more on this issue). This happens in the following English example:

(20) I unintentionally managed to make him feel that he is responsible for our safety.

Similarly, (18) also has a reading in which John does not specifically work on losing weight, but it just happens to him. The prominent reading is the one when there is a try, but such goal-oriented behaviour is not required for this sentence to be true. What (19) shows is that the dative argument of sikerül can only be + ANIMATE. Even if dishwashers can undergo tests, we cannot report such an event with this construction. ${ }^{12}$

What I propose here is that Hungarian dative case has a special lexical entry, which can be regarded, at least in the semantic sense, as some sort of a spell out of the semantics that characterises the Hungarian verb sikerül 'manages to, succeeds': 13

(21) - $n V k:\left[\mathrm{N}_{-}\right] \mathrm{N}$, 'MANAGE $<\left(\arg _{1}\right)\left(\arg _{2}\right)>$ '

By (21), dative case can function in Hungarian as a dyadic predicate, taking a causer argument and a propositional argument (the caused eventuality described by the predicative core of the sentence). The name of the semantic predicate is MANAGE because of the arguments made above. This falls short of a detailed semantic analysis, but the simple claim I want to make here is that a close analogy can be drawn between the se-

12 The verb can also take an infinitival complement:

(i) A mosógép-nek megint sikerült el-romla-ni-a.

the dishwasher-DAT again managed PRT-break.down-INF-3SG

'The dishwasher managed to break down again.'

However, the dative in this case is the (raised) subject of the agreement-marked infinitive, and bears no thematic or semantic relation towards the finite verb (see Rákosi 2006, chapter 6 for an overview of this construction).

${ }^{13}$ I use LFG-type notation here to represent the argument structure of the causally interpreted dative case. See Bresnan (2001) for an overview of LFG, and Butt \& King (2004) for an LFG approach to semantically contentful case-markers. 
mantics of the verb sikerül 'manages to' and the semantics of Hungarian dative causers. This analysis can explain the observed behaviour of dative causers on grounds of the parallelism with the dative argument of sikerül: dative causers must be + ANIMATE for the same reason that the dative argument of sikerül is +ANIMATE; dative causers are interpreted as general causers whose exact relation to the caused eventuality is determined by the syntactic and pragmatic context in which they occur for the same reason that the dative argument of sikerül is also interpreted that way; and, finally, dative causers are most naturally used in Hungarian if the implication that there is a try is present and sikerül also behaves the same way.

The reason why reading $\mathrm{C}$ is preferred in Hungarian over the other two causer readings also follows from this set of assumption. The tryimplication is normally present with dative causers in Hungarian, and that triggers reading $\mathrm{C}$. Reading $\mathrm{A}$ is most natural in a context in which this implication can be cancelled. ${ }^{14}$ I repeat (7) to illustrate.

(7) a. Kati-nak fel-robbant egy kémcső.

Kate-DAT PRT-exploded a test.tube.NOM

'Kate accidentally exploded a test-tube.'

b. Kati-nak be-tört egy ablak.

Kate-DAT PRT-broke a window.NOM

'Kate accidentally broke the window.'

In 2.2, I have argued that (7a) sounds more natural than (7b), because the event described in the former case is more likely to happen without an external cause than in the case of the latter. It is for this reason that it is easier to cancel the try-implication in (7a) than in (7b): the context better supports this cancellation in the case of (7a).

Dative causers must be inserted high to be able to combine with their second argument, that is why they typically occur on the left edge of the clause. Since a detailed syntactic analysis is not among the objectives of this paper, I do not discuss the syntax of Hungarian dative causers in more detail. I only want to add that the predicative analysis in (21) does not force us to postulate a biclausal structure for dative causer constructions, and there is no positive evidence for such an analysis. Dative causers are merged in monoclausal structures, and this insertion, as we have seen, is a syntactically free operation in Hungarian given the existence of (21).

\footnotetext{
${ }^{14}$ I thank Dmitry Ganenkov for emphasizing this point to me.
} 


\subsection{Some reasons to reject the constructionalist analysis for Hungarian}

The dominant view in the syntactic literature is that dative causers are licensed via the syntactically decomposed event structure (or: argument structure) of the clause (see Cuervo 2003; Kallulli 2006; 2007; McIntyre 2006; Schäfer 2008; 2009; 2012). I illustrate this approach with the applicative analysis of Cuervo (2003) and Schäfer (2008; 2009; 2012), disregarding now the variation across the above proposals as not directly relevant for our purposes.

Consider (22) for illustration (Schäfer 2008, 154):

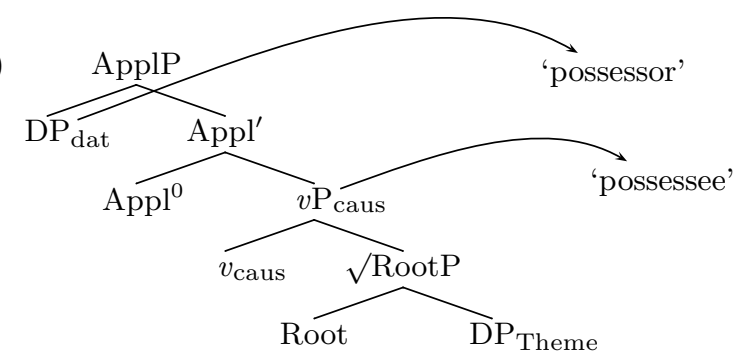

In this structure, the dative causer is merged into the specifier position of a high applicative phrase. This type of ApplP can take a causative $v \mathrm{P}$ as its complement in the absence of an external argument (which would be hosted by VoiceP, see Alexiadou et al. 2006). The applicative head itself only spells out some vague possessive relation, and the dative qua a possessor is taken "to have a causative event". ${ }^{15}$ This vague relation is thus interpreted at the interface as a causal relation between a participant and an eventuality.

The appeal of this analysis is that it can explain why dative causers are restricted to inchoative structures in German or in the other languages discussed in the literature, and it also explains how the weak sort of causation that we see attested in dative causer constructions arises. It also explains why the weakest of these readings, the true unintended causation reading, is the one that is the default in German. Readings B and C, which are semantically more complex, require more effort to build, so they have a somewhat marked character.

I have argued here, however, that in Hungarian the markedness scale seems to go in the other direction (from reading $\mathrm{C}$ being often the more

\footnotetext{
${ }^{15}$ See also McIntyre (2006) for an analysis that draws on the analogy between pos-
} sessors and dative causers. 
natural choice to reading A being less easily available in many cases), and that dative causers in Hungarian are not primarily constrained by the syntactic structure into which they are merged. Here I would like to provide two further arguments to claim that Hungarian dative causers are indeed qualitatively different from their German or Albanian counterparts.

We have noted that dative causers are not compatible with intentionality or agentive modifiers. Schäfer (2008, 100), for example, shows that dative causers in German cannot co-occur with instrument adjuncts:

(23) Dem Peter ist die Vase $\left({ }^{*}\right.$ mit dem Hammer $)$ zerbrochen.

the.DAT Peter is the.NOM vase with the hammer broken

'Peter accidentally broke the vase (with the hammer).'

This is a very strong restriction on dative causers and it distinguishes them from transitive non-agentive subjects, which, as the English translation shows, are compatible with instrumental modifiers. Hungarian dative causers, however, are not subject to this constraint (or at least not under reading $\mathrm{C})$ :

(24) a. Kati-nak könnyen ki-nyílt a zár a kulcs-csal.

Kate-DAT easily PRT-opened the lock.NOM the key-with

'Kate managed to open the lock easily with the key.'

b. Kati-nak sikerült a fogyás az új tablettá-val.

Kate-DAT succeeded the losing.weight.NOM the new pill-with

'Kate managed to lose weight with the new pill.'

Note again the parallel between the behaviour of the dative causer (24a) and the verb sikerül 'succeeds, manages' in (24b), which provides further evidence for the analysis presented above in (21).

Another indication that Hungarian datives causers are of a distinct type comes from their ability to co-occur with ablative causes. As discussed in Rákosi (2009; 2012), low ablative causes are licensed by inchoative change of state verbs Hungarian, much like from-causes in the selfsame contexts in English:

(25) Az ablak ki-nyílt a huzat-tól.

the window.NOM out-opened the draught-ABL

'The window opened from the draught.' 
Kallulli $(2006,280)$ shows with respect to Albanian and German data that such low level cause-PPs are incompatible with dative causers. Consider the following German example: ${ }^{16}$

(26) Der Anna ist das Fenster durch den Wind zerbrochen.

the.DAT Anna is the.NOM window through the.ACC Wind broken.

'*Anna unintentionally broke the window through the wind?'

In the constructionalist approach to such data, syntactic structure is assumed to have the potential to license a single cause at a time. An alternative, but not necessarily entirely distinct, explanation is that two causes cannot occur in same clause since that would violate uniqueness (cf. McIntyre 2006).

One can nevertheless still construe such examples in Hungarian.

(27) Kati-nak be-sárgultak az ingek mosás közben a rossz mosópor-tól.

Kate-DAT PRT-yellowed the shirts washing during the bad detergent-ABL

'Kate unintentionally let the shirts go yellow from the bad detergent during washing.'

I think the possibility of this co-occurrence is expected if we assume that both of these causes are inherently specified for a causal relation and they do not gain their interpretation via the syntactic structure. Rákosi (2009; 2012) argues that ablative causes in Hungarian do genuinely introduce causation into the sentence, and they do not feed on a causal light verb (or a causal feature on a light verbal head) in the structure. Therefore ablative causes do not provide evidence that change of state intransitives are causative in a syntactically or semantically relevant sense.

I have made the same argument above about dative causers: they are lexically specified to be causal, and they do not feed on a causatively interpreted clausal structure. Given that both dative and ablative causes have the capacity to introduce a cause on their own right, it is not a priori ruled out that they can co-occur. ${ }^{17}$ And, finally, the contrast between (26) and (27) is yet another indicator that Hungarian dative causers are not

16 (26) is well-formed if the dative is interpreted as a possessor or as an affected participant. These readings are not relevant for us.

17 (27) is only an apparent violation of thematic uniqueness if we assume that the two causes are of the same thematic/semantic type. Space limitations do not allow me to compare ablative causes with dative causes in any detail, but the two clearly have diverging syntactic and semantic properties. 
grammatically equivalent to dative causers in German and in languages treated on a par with German in the literature.

\section{Conclusions}

I have made an effort in this paper to survey the landscape of dative causers in Hungarian and to compare what I find with better known data from a variety of languages discussed in the literature. I have argued that Hungarian dative causers differ from the dative causers found in many other languages: they are grammatical by any predicate type and they are lexically specified to introduce a causal relation akin to the one expressed by the verb manage. Consequently, they show a preference for the managereading, and the true unintended causation reading often sounds marked in Hungarian. In a way, these dative causers resemble certain causative uses of the English prepositions to and for.

It remains to be investigated to what extent this sort of relatively free oblique causer is present cross-linguistically, and what factors may govern its availability in particular languages. It has been noted for German oblique causers that they may have manage-readings (see Schäfer 2012 and Martin \& Schäfer to appear), and Davis et al. (2009) make the same observation for the so called 'out of control'-morphology in St'at'imcets. But, unlike in Hungarian, these constructions are restricted to specific verbal classes (typically to anticausative/decausativized verbs), and they have several readings, of which the manage-reading is not the most easily accessible one. These constructions are therefore not equivalent to the Hungarian dative causer construction that I have discussed in this article.

\section{Acknowledgements}

This paper presents the revised version of the talk that I gave at the workshop on Morphological Voice and its Grammatical Interfaces in Vienna in 2010. I thank the audience of the Vienna workshop for their useful comments and discussion. I am also grateful to the two reviewers of this paper for their detailed comments on the first draft. Any remaining errors are solely mine. I gratefully acknowledge furthermore that the research reported here is supported by OTKA (Hungarian Scientific Research Fund), grant number NK 100804. 


\section{References}

Alexiadou, Artemis, Elena Anagnostopoulou and Florian Schäfer. 2006. The properties of anticausatives crosslinguistically. In M. Frascarelli (ed.) Phases of interpretation. Berlin \& New York: Mouton de Gruyter. 187-21.

Baglini, Rebekah and Itamar Francez. 2013. The implications of managing. Handout given at the 31st Annual Meeting of the West Coast Conference on Formal Linguistics, Tempe.

Bresnan, Joan. 2001. Lexical-functional syntax. Malden MA \& Oxford: Blackwell.

Butt, Miriam and Tracy Holloway King. 2004. The status of case. In V. Dayal and A. Mahajan (eds.) Clause structure in South Asian languages. Dordrecht: Kluwer. 153-198.

Cuervo, María Cristina. 2003. Datives at large. Doctoral dissertation. MIT.

Davis, Henry, Lisa Matthewson and Hotze Rullmann. 2009. 'Out of control' marking as circumstantial modality in St'at'imcets. In L. Hogeweg, H. de Hoop and A. Malchukov (eds.) Cross-linguistic semantics of tense, aspect, and modality. Amsterdam \& Philadelphia: John Benjamins. 205-244.

Dikken, Marcel den. 1999. On the structural representation of possession and agreement: The case of (anti-)agreement in Hungarian possessed nominal phrases. In I. Kenesei (ed.) Crossing boundaries: Advances in the theory of Central and Eastern European languages. Amsterdam \& Philadelphia: John Benjamins. 137-178.

É. Kiss, Katalin. 2000. The Hungarian noun phrase is like the English noun phrase. In G. Alberti and I. Kenesei (eds.) Approaches to Hungarian 7: Papers from the Pécs conference. Szeged: JATEPress. 121-149.

Fauconnier, Stefanie. 2011. Involuntary agent constructions are not directly linked to reduced transitivity. Studies in Language 35. 311-336.

Ganenkov, Dmitry, Timur Maisak and Solmaz Merdanova. 2008. Non-canonical agent marking in Agul. In H. de Hoop and P. de Swart (eds.) Differential subject marking. Dordrecht: Kluwer. 173-198.

Hole, Daniel, André Meinunger and Werner Abraham (eds.). 2006. Datives and other cases. Amsterdam \& Philadelphia: John Benjamins.

Kallulli, Dalina. 2006. Unaccusatives with dative causers and experiencers: A unified account. In Hole et al. (2006, 271-301).

Kallulli, Dalina. 2007. Rethinking the passive/anticausative distinction. Linguistic Inquiry $38.770-780$.

Kittilä, Seppo. 2005. Remarks on involuntary agent constructions. Word 56. 381-419.

Levin, Beth and Malka Rappaport Hovav. 1995. Unaccusativity. At the syntax-lexical semantics interface. Cambridge MA: MIT Press.

Martin, Fabienne and Florian Schäfer. to appear. Causation at the syntax-semantics interface. In B. Copley and F. Martin (eds.) Causation in grammatical structures. Oxford: Oxford University Press.

Matushansky, Ora. 2012. On the internal structure of case in Finno-Ugric small clauses. Finno-Ugric Languages and Linguistics 1. 3-43.

McIntyre, Andrew. 2006. The interpretation of German datives and English have. In Hole et al. (2006, 185-212).

Acta Linguistica Hungarica 61, 2014 
Rákosi, György. 2006. Dative experiencer predicates in Hungarian. Doctoral dissertation. Utrecht. Published as LOT Dissertations, vol. 146, Utrecht: Uil-OTS.

Rákosi, György. 2008. Some remarks on Hungarian ethical datives. In J. Andor, B. Hollósy, T. Laczkó and P. Péter (eds.) When grammar minds language and literature. Festschrift for Prof. Béla Korponay on the occasion of his 80th birthday. Debrecen: Institute of English and American Studies, University of Debrecen. 413-422.

Rákosi, György. 2012. In defence of the non-causative analysis of anticausatives. In M. Everaert, M. Marelj and T. Siloni (eds.) The theta system: Argument structure at the interface. Oxford: Oxford University Press. 177-199.

Reinhart, Tanya. 1996. Syntactic effects of lexical operations: Reflexives and unaccusatives (Uil-OTS Working Papers in Linguistics 97-002). Utrecht: University of Utrecht.

Reinhart, Tanya. 2002. The Theta System: An overview. Theoretical Linguistics 28. 229-290.

Rivero, María Luisa. 2004. Datives and the non-active voice/reflexive clitics in Balkan languages. In O. M. Tomic (ed.) Balkan syntax and semantics. Amsterdam \& Philadelphia: John Benjamins. 237-267.

Schäfer, Florian. 2008. The syntax of (anti-)causatives. Amsterdam \& Philadelphia: John Benjamins.

Schäfer, Florian. 2009. The oblique causer construction across languages. In A. Schardl, M. Walkow and M. Abdurrahman (eds.) Proceedings of NELS 38. Amherst, MA: GLSA. 297-308.

Schäfer, Florian. 2012. Two types of external argument licensing - The case of causers. Studia Linguistica 66. 128-180.

Szabolcsi, Anna. 1983. The possessor that ran away from home. The Linguistic Review 3. $216-89$

Tóth, Ildikó. 2000. Inflected infinitives in Hungarian. Doctoral dissertation. Tilburg University.

Ürögdi, Barbara. 2006. Predicate fronting and dative case in Hungarian. Acta Linguistica Hungarica 53. 291-332. 